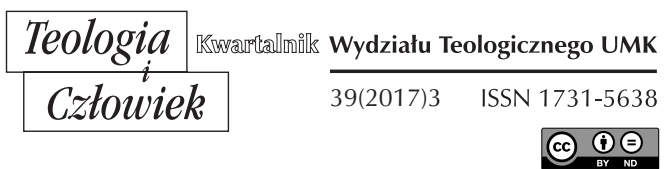

KS. ARTUR NIEMIRA*

WŁOCŁAWEK

\title{
MORALNY WYMIAR SAKRAMENTU CHRZTU W ŚWIETLE ENCYKLIKI LUMEN FIDEI PAPIEŻA FRANCISZKA
}

DOI: http://dx.doi.org/10.12775/TiCz.2017.027

Chrzest święty - pierwszy z sakramentów, jaki człowiek przyjmuje w swoim życiu, będący jednym z trzech sakramentów inicjacji chrześcijańskiej, stanowi fundament całej chrześcijańskiej egzystencji i wprowadza (wtajemnicza) w życie wiary. Pociąga za sobą zatem konsekwencje o charakterze moralnym, czyli wpływa i warunkuje osobowe życie chrześcijanina jako podmiotu wolnego, świadomego i odpowiedzialnego, który kieruje się w stronę dobra. Można więc mówić o moralnym wymiarze sakramentu chrztu świętego, na co wskazał papież Franciszek w swojej pierwszej encyklice Lumen fidei: „Człowiek otrzymuje w chrzcie naukę, którą ma wyznawać, oraz konkretną formę życia, która wymaga zaangażowania całej jego osoby i kieruje go w stronę dobra"1.

* Ks. Artur Niemira - prezbiter diecezji włocławskiej, absolwent Papieskiego Uniwersytetu Gregoriańskiego w Rzymie. Prowadzi zajęcia z teologii moralnej w Wyższym Seminarium Duchownym we Włocławku oraz na Wydziale Teologicznym UMK w Toruniu, od 2004 r. kanclerz Kurii Diecezjalnej we Włocławku, autor artykułów z zakresu teologii moralnej fundamentalnej i szczegółowej (artniem@gmail.com).

${ }^{1}$ Franciszek, Lumen fidei, 41. Odtąd skrót: LF 
Należy zatem przypatrzeć się istocie sakramentu chrztu, zwrócić uwagę na związek pomiędzy wiarą przyjętą a życiem chrześcijanina, by wreszcie wskazać na zobowiązania wypływające z przyjęcia pierwszego z siedmiu sakramentów świętych.

\section{ISTOTA CHRZTU - SAKRAMENT NOWEGO ŻYCIA}

Misyjny nakaz Chrystusa: „Idźcie więc i nauczajcie wszystkie narody, udzielając im chrztu w imię Ojca i Syna, i Ducha Świętego” (Mt $28,19)$ zalicza przyjęcie chrztu do najważniejszych wydarzeń w życiu wierzących. Co więcej, Pan Jezus uzależnił osiągnięcie zbawienia nie tylko od przyjęcia Jego nauki, ale również od przyjęcia chrztu: „Kto uwierzy i przyjmie chrzest będzie zbawiony" (Mk 16,16) ${ }^{2}$.

Katechizm Kościoła Katolickiego stwierdza więc, że chrzest święty jest „fundamentem całego życia chrześcijańskiego, bramą życia w Duchu i bramą otwierającą dostęp do innych sakramentów. Przez chrzest zostajemy wyzwoleni od grzechu odrodzeni jako synowie Boży, stajemy się członkami Chrystusa oraz zostajemy wszczepieni w Kościół”3.

Należy zauważyć, że w świetle Nowego Testamentu chrzest jest ukazywany jako ponowne narodzenie się z wody i Ducha Świętego ${ }^{4}$. Najbardziej znanym fragmentem mówiącym o tym jest rozmowa Pana Jezusa z Nikodemem: „Zaprawdę, zaprawdę powiadam ci, jeśli się ktoś nie narodzi z wody i z Ducha, nie może wejść do Królestwa Bożego" (J 3,5). Święty Paweł z kolei nazywa chrzest „obmyciem odradzającym i odnawiającym w Duchu Świętym” (Tt 3,5). Źródłem chrzcielnego odrodzenia jest męka, śmierć i zmartwychwstanie Jezusa Chrystusa ${ }^{5}$, stąd jak przypomina Katechizm Kościoła Katolickiego, sakrament ten nosi swoją nazwę dla wskazania na główny obrzęd, przez który jest wypełniany: chrzcić znaczy zanurzyć $\mathrm{w}$ wodzie, co jest symbolem pogrzebania w śmierci

${ }^{2}$ Por. J. Misiurek, Wiara i sakramenty w życiu duchowym, Częstochowa 2013, s. 215 .

${ }^{3}$ KKK, 1213.

${ }^{4}$ Por. P. Kreeft, Sakrament chrztu i bierzmowania, Warszawa 2011, s. 13.

${ }^{5}$ Por. J. Misiurek, Wiara i sakramenty, s. 215. 
Jezusa, z którego powstaje przez zmartwychwstanie z Nim jako nowe stworzenie ${ }^{6}$.

Chrzest jest wszczepieniem w Chrystusa, włączeniem w Jego mękę, śmierć i zmartwychwstanie, co dokonuje się przez obmycie „wodą, któremu towarzyszy słowo” (por. Ef 5,26). „Słowo” w opinii egzegetów oznacza formułę chrzcielną, która tłumaczy i uzasadnia zanurzenie bądź polanie wodą $^{7}$. Uobecniona zostaje cała rzeczywistość Boska w nim zawarta, a wydarzenie zbawcze uobecnia się w sposób ponadhistoryczny, a więc w sposób sakramentalny. W tym sensie chrzest staje się rzeczywistością udzielonego przez Chrystusa nowego życia, w którym ochrzczony ma uczestnictwo ${ }^{8}$. Poprzez chrzest wyraża się zatem paschalny charakter życia chrześcijańskiego. Pierwszy sakrament jest przejściem, porzuceniem stanu grzesznego i wejściem w nowe życie, a zatem w Nowe Przymierze. Chrzest gładzi grzech pierworodny, dzięki czemu człowiek staje się na nowo dzieckiem Bożym, oraz zapoczątkowuje życie w łączności z Chrystusem. Nie ma też innej drogi włączenia we wspólnotę Kościoła, jak właśnie poprzez chrzest. Znakiem nieodwołalnego wkorzenienia ochrzczonego w Kościół jest tak zwany niezatarty charakter sakramentalny ${ }^{9}$. Franciszek podkreśla te wymiary sakramentu chrztu w swojej encyklice: „W chrzcie stajemy się nowym stworzeniem, przybranymi synami Bożymi, uczestnikami Boskiej natury, członkami Ciała Chrystusa" ${ }^{\prime 10}$.

Chrzest ma więc charakter wybitnie paschalny, to znaczy jest sakramentem wyzwolenia i przejścia z niewoli do wolności, z grzechu do świętości, z niewoli prawa do życia łaską. Tym samym inicjacja chrześcijańska, związana z chrztem, jest rytem przejścia, co oznacza, że zostawia się jeden stan, by wejść w inny - stan grzechu, by wejść w stan łaski. Staje się sakramentem wiary jako odrzucenie błędu i grzechu a przyjęcie świadome i wolne Ewangelii. Chrzest jako taki jest sakramentem mają-

${ }^{6}$ Por. KKK, 1214.

7 Por. J. Hadalski, Osobotwórczy charakter chrztu, Kraków 2006, s. 122-123.

${ }^{8}$ Por. D. Brzeziński, Liturgia chrześcijańska jako celebracja wiary. Refleksja na marginesie listu apostolskiego Benedykta XVI Porta fidei ogłaszajacego Rok Wiary, AK 160(2013), z. 3(625), s. 444-445.

9 Por. A. Skowronek, Z teologii chrztu, w: Sakrament chrztu. Liturgia, teologia, Pismo św., red. St. Czerwik, J. Kudasiewicz, J. Łach, A. Skowronek, Katowice 1973, s. 26. ${ }^{10} \mathrm{LF}, 41$. 
cym strukturę dramatyczną: jest aktem, działaniem, przez które zerwane zostają sznury, którymi człowiek jest związany, zerwany łańcuch, który czyni z niego więźnia; jest decyzją wyjścia z ziemi niewoli, by wejść do ziemi obiecanej wolności. Wyjaśnia to, jak bardzo ten sakrament jest dla ludzi zdolnych do wolnych wyborów i do osobistego zaangażowania. Nie oznacza to, że chrzest miałby być sakramentem przeznaczonym tylko dla ludzi dorosłych. W wolności można się także urodzić i nie musi ona być dobrem, które koniecznie trzeba zdobyć, co nie przeczy twierdzeniu, że w wolności można żyć tylko dzięki osobistemu wyborowi. W wolności można się urodzić, wolnymi można się tylko stawać. Nowe życie otrzymane na chrzcie świętym nie jest rzeczywistością statyczną, ale wzrasta wraz z człowiekiem, podobnie jak wszystko, co jest w świecie stworzone. Tak jak następuje wzrost i rozwój fizyczny, tak dzień po dniu dojrzewają wolność i człowieczeństwo. Podobnie człowiek ochrzczony każdego dnia musi swoje chrześcijaństwo formować, by prawdziwie być chrześcijaninem ${ }^{11}$.

Sakrament chrztu inicjuje zatem nowe życie w Chrystusie, otwiera przed człowiekiem rzeczywistość eschatologiczną wskazując drogę ku życiu wiecznemu. Więź z Jezusem Chrystusem jest czymś sakramentalnie niezatartym - ochrzczony staje się ontologicznie "Chrystusowy”, otrzymuje moc do życia według nowego przymierza, które On zawarł przez Swoją mękę, śmierć i zmartwychwstanie, co znów nie oznacza, że to nowe życie jest rzeczywistością statyczną - Chrystus uzdalnia człowieka do takiego życia, ale też sam ochrzczony jest wezwany do rozwijania więzi z Chrystusem i życia Nim. Na tej drodze ochrzczony nie jest sam, Jezus mu towarzyszy, udziela Ducha Świętego, a przez Niego - światła i mocy do kroczenia po drodze chrześcijańskiego życia ${ }^{12}$.

Stwierdzenie, że od momentu chrztu człowiek nie jest sam, ma jeszcze inne znaczenie - pierwszy z sakramentów włącza ochrzczonego w Kościół, czyni go jego członkiem i wprowadza we wspólnotę, w której każdy podąża drogą życia w Chrystusie prowadzącą do zbawienia. Przez chrzest wspólnota Kościoła przyjmuje nowego członka dając mu dostęp do łask, które są owocem pozostałych wiary pozostałych członków wspólnoty

11 Por. A. Santantoni, Iniziazione cristiana: concetto e realtà, w: Corso di morale. 5 - Liturgia. Etica della religiosità, red. T. Goffi, G. Piana, Brescia 1995, s. 148-149.

12 Por. S. Olejnik, Teologia moralna życia osobistego, Włocławek 1999, s. 28. 
kościelnej. To rodzi poczucie przynależności do tej wspólnoty, które oznacza nawiązanie głębszych więzi eklezjalnych oraz świadome i dobrowolne przyjęcie obowiązków kościelnych ${ }^{13}$.

Wynika stąd jasno, że chrzest inicjuje życie wiarą, jest sakramentem rozpalającym ogień wiary. Chrzest jest fundamentem życia w wierze i źródłem cnoty wiary. Mówiąc o tym, że chrzest zapoczątkowuje życie wiarą należy podkreślić, że dzieje się tak u tych, którym udziela się go przed dojściem do używania rozumu. Natomiast osobom dorosłym udziela się tego sakramentu, gdy mogą już sami o sobie decydować, co oznacza, że chrzest powinien być poprzedzony aktem wiary ${ }^{14}$. W obu jednak przypadkach wiara jest łaską, Kościół przekazuje wiarę, poprzez środki, którymi są sakramenty ${ }^{15}$. Dlatego mówiąc o moralnym wymiarze sakramentu chrztu należy przyjrzeć się bliżej relacji między wiarą a chrześcijańską egzystencją.

\section{SAKRAMENT WIARY}

Encyklika Lumen fidei mocno akcentuje, że chrzest święty jest sakramentem, poprzez który ochrzczonemu przekazana zostaje wiara, jest sakramentem wiary ${ }^{16}$. To stwierdzenie niesie w sobie bogaty w treść przekaz dla chrześcijańskiej egzystencji. Najpierw wskazuje na wymiar eklezjalny i wspólnotowy, w którym człowiek otrzymuje dar wiary i go rozwija. Franciszek stwierdza, że wiara „przekazywana jest od osoby do osoby, podobnie jak płomień zapala się od innego płomienia"17. Właśnie dlatego papież naucza, że wiara przekazywana jest jako słowo i jako światło. Odnosi się do tekstów św. Pawła Apostoła: „uwierzyłem, dlatego przemówiłem, my także wierzymy, dlatego mówimy” (2 Kor 4,13) oraz „wpatrujemy się w jasność Pańską jakby w zwierciadle (...), coraz bardziej jaśniejąc upodobniamy się do Jego obrazu” (2 Kor 3,18). Światło

13 Por. J. Przybyłowski, Chrzest w praktyce duszpasterskiej, „Studia Włocławskie” 17 (2015), s. 225.

14 Por. S. Olejnik, Teologia moralna życia osobistego, s. 28.

15 Por. LF, 40.

16 Por. LF, 41.

17 LF, 37. 
Chrystusa odbija się na obliczu chrześcijan i tak się rozchodzi, by każdy mógł mieć w nim udział ${ }^{18}$.

Franciszek podkreśla, że to oblicze Jezusa dociera do współcześnie żyjących dzięki nieprzerwanemu łańcuchowi świadectwa przekazywanemu z pokolenia na pokolenie. Taka jest droga przekazu wiary: doświadczenie osobistego spotkania z Jezusem Chrystusem, które odbywa się w konkretnym momencie historii życia człowieka, staje się światłem oświecającym jego drogę w czasie, by być przekazywanym przez wieki. Pewność przeka$\mathrm{zu}$ "prawdziwego Jezusa” gwarantuje coś, co w encyklice zostaje nazwane „Zachowaniem żywej pamięci”19. Ma to związek z prawdą o charakterze egzystencjalnym, a mianowicie że pamięć budowana jest przez międzyosobową relację, w jakiej człowiek się rozwija, poznaje siebie i innych. Także egzystencja chrześcijańska ma wymiar relacyjny: „Przeszłość wiary, dzieło miłości Jezusa, które zrodziło w świecie nowe życie, dociera do nas w pamięci innych, świadków, jest zachowane i żywe w tym jednym podmiocie, pamięci, jakim jest Kościół. Kościół jest Matką uczącą nas mówić językiem wiary"20.

W dokumencie pojawia się stwierdzenie, które stało się jednym z najbardziej charakterystycznych wyrażeń pierwszej encykliki obecnego papieża: „Nie można wierzyć samotnie. (...) Ten kto wierzy, nigdy nie jest sam”21. Ta ważka treściowo wypowiedź uzmysławia fakt, że wiara nie jest tylko indywidualnym wyborem człowieka, nie jest odizolowaną relacją z Panem Bogiem, ale ze swej natury wydarza się zawsze we wspólnocie Kościoła, o czym przypomina między innymi dialogowana forma Credo stosowana podczas liturgii chrzcielnej. Liturgia sakramentu chrztu świętego urzeczywistnia wewnętrzny charakter wiary, jaką ochrzczony zostaje w tym sakramencie obdarzony - jej dialogiczny charakter. Wiara jest odpowiedzią na zaproszenie, na słowo, jakie Bóg kieruje do człowieka, włącza w dialog, który nie może być tylko wyznawaniem słowem, ale domaga się realizacji (wyznawania) w życiu. Ten dialog nie płynie wyłącznie od jednostki, ale na zaproszenie do przyjęcia wiary można odpowiedzieć

\footnotetext{
18 Por. Tamże.

19 Por. LF, 38.

20 Tamże.

21 LF, 39.
} 
w pierwszej osobie tylko dlatego, że należy się do wspólnoty, która mówi: „wierzymy”. Taką dynamiką charakteryzuje się miłość, na którą chrzest otwiera, przez co wiara ze swej natury dąży do tego, by się rozpowszechniać, by zapraszać innych do rodziny wierzących ${ }^{22}$.

W tym procesie nieodzowną rolę pełnią sakramenty Kościoła, zwłaszcza chrzest. Kościół przekazuje to, co przechowuje w swojej pamięci, żeby pomóc swoim dzieciom prowadzić życie święte, przyczyniać się do wzrostu wiary. Papież Franciszek przyznaje, że gdyby wiara polegała tylko na przyjęciu umysłem pewnych doktrynalnych prawd czy idei, to prawdopodobnie do jej przekazu wystarczyłaby jakaś mądra książka. Jednak tym, co przekazuje się w Kościele za pomocą specjalnego środka, jakim są sakramenty, ,jest nowe światło, rodzące się ze spotkania z Bogiem żywym, światło, które sięga centrum osoby, jej serca, angażując jej umysł, jej wolę, oraz jej życie uczuciowe, otwierając ją na żywe relacje w komunii z Bogiem i innymi ludźmi”, dlatego że „w nich przekazywana jest pamięć wcielona, związana $\mathrm{z}$ miejscami i okresami życia, zespolona ze wszystkimi zmysłami; osoba jest w nich włączona, jako członek żywego podmiotu, w tkankę relacji wspólnotowych"²3. Już wiele lat wcześniej Joseph Ratzinger napisał, że wiara nie jest czystą teorią, zbiorem prawd do przyjęcia przez rozum, ale oznacza też praxis. Działanie moralne chrześcijanina wypływa z jego zakorzenienia w Chrystusie. Dlatego każda chrześcijańska propozycja moralna jest zarazem moralna i chrystologiczna, a życie moralne ma charakter chrystocentryczny ${ }^{24}$.

W stwierdzeniach Franciszka pobrzmiewają inne słowa wielkiego poprzednika obecnego papieża, św. Jana Pawła II, który poświęcając uwagę zależności pomiędzy wiarą a moralnością, w encyklice Veritatis splendor podkreślił znacząco, że wiara nie jest jedynie zbiorem twierdzeń wymagających przyjęcia i zatwierdzenia przez rozum. Jest natomiast poznaniem Chrystusa w wewnętrznym doświadczeniu, żywą pamięcią o Jego przykazaniach, prawdą, którą trzeba żyć ${ }^{25}$. Oznacza to, że wiara angażuje całą egzystencję chrześcijanina. Wiara posiada wymiar moralny,

${ }^{22}$ Por. Tamże.

${ }^{23}$ LF, 40.

${ }^{24}$ Por. J. Ratzinger, Presentazione, w: Veritatis Splendor. Testo integrale e commento filosofico-teologico, red. R. Lucas Lucas, Cinisello Balsamo 1994, s. 8.

${ }^{25}$ Por. Jan Paweł II, Veritatis splendor, 88. 
„jest źródłem zgodnego z nią życiowego zaangażowania”, konkretnych postaw, podejmowanych decyzji na wzór samego Chrystusa, a zarazem niesie zapisane w sobie zobowiązanie. Idąc dalej, św. Jan Paweł II uczył, że wiara to decyzja, która angażuje całe życie. Jest spotkaniem, dialogiem, komunią miłości i życia między wierzącym a Jezusem Chrystusem. Wiara prowadzi do aktu zaufania i zawierzenia Chrystusowi i pozwala żyć tak, jak On żył (por. Ga 2,20), to znaczy miłując ponad wszystko Boga i braci. Wiara domaga się również przyjęcia i zachowywania Bożych przykazań. Poprzez życie moralne wiara staje się „wyznaniem”, nie tylko wobec Boga, ale także przed ludźmi: staje się świadectwem ${ }^{26}$. Można więc powiedzieć, że bez sakramentów wyznawanie wiary byłoby bezskuteczne, ponieważ brakowałoby łaski, która uzdalnia do dawania takiego świadectwa ${ }^{27}$.

Jeśli poprzez sakramenty człowiek wchodzi w relację z Chrystusem, doświadcza sensu własnej egzystencji oraz mocy łaski, dzięki której poznaje prawdę o Jezusie, to zaznaczyć należy, że dar oznacza także zobowiązanie (zarówno dla Kościoła, jak i dla poszczególnego wiernego) do radykalnego upodabniania się do Chrystusa ${ }^{28}$. Chrzest święty jawi się tutaj jako sakrament, w którym ochrzczony otrzymuje nową formę życia, która zgodnie z wcześniejszymi stwierdzeniami, wymaga zaangażowania całej jego osoby, nie samotnie lecz we wspólnocie, z nową formą działania nie w pojedynkę lecz w Kościele, bo wiara nie jest dziełem jednostki liczącej na własne siły, ale musi być przyjęta poprzez wejście do wspólnoty kościelnej: „nikt sam nie udziela sobie chrztu, podobnie jak nikt sam nie rodzi się do życia"29. Wiara wymaga więc przyjęcia daru i wyruszenia $\mathrm{w}$ drogę - nie w pojedynkę, ale z Chrystusem i we wspólnocie wierzących. Jest to droga naznaczona nieco niepewnością, gdyż prowadzi w nieznane, ale zarazem wymagająca zaufania, a więc oparta na nadziei, jako że jest drogą, którą jako pierwszy idzie sam Zbawiciel ${ }^{30}$.

26 Tamże, 89.

27 Por. Cz. Parzyszek, Treść dokumentu Instrumentum Laboris dla Synodu Biskupów o nowej ewangelizacji, AK 159(2012), z. 3(622), s.497.

${ }_{28}$ Por. B. Häring, Esistenza cristiana e liturgia, w: Nuovo Dizionario di Liturgia, red. D. Sartore - A.M. Triacca, Roma 1984, s. 477.

${ }^{29} \mathrm{LF}, 41$.

${ }^{30}$ Por. J. Szymański, Zadania wierzacych odczytane $w$ liście apostolskim Porta fidei, AK 159(2012), z. 3(622), s. 423. 


\section{NAŚLADOWANIE CHRYSTUSA ŻYCIOWĄ DROGĄ OCHRZCZONEGO}

Z wcześniejszych rozważań wyłaniają się konsekwencje przyjętego chrztu dla życia chrześcijanina, moralne zobowiązania, których źródłem jest pierwszy sakrament wtajemniczenia chrześcijańskiego. W tym zawiera się owa konkretna forma życia, która wymaga zaangażowania całej osoby i kieruje wierzącego w stronę dobra, o czym zostało wspomniane wyżej $^{31}$. Poszukiwanie dobra jest kategorią moralną. Dotyczy osoby jako podmiotu wolnego, świadomego i odpowiedzialnego, która podejmując decyzje, dokonując wyboru Chrystusa, odpowiadając na dar nowego życia w Chrystusie, w wolności poszukując prawdy, kieruje się ku dobru. Przyjęcie chrztu ma wymiar fundamentalny dla chrześcijańskiej egzystencji, jest bowiem realizacją samej istoty bycia chrześcijaninem - niesie z sobą odrodzenie, które otwiera drogę naśladowania Chrystusa w Jego nowej egzystencji ${ }^{32}$. Franciszek zaznacza, że działanie Chrystusa w sakramencie chrztu dotyka rzeczywistości osobowej chrześcijanina, przemienia radykalnie sprawiając, że ochrzczony staje się przybranym dzieckiem Bożym, uczestnikiem Jego Boskiej natury. Skutki sakramentu mają przełożenie na wymiar egzystencjalny: „modyfikuje w ten sposób wszystkie nasze relacje, naszą konkretną sytuację w świecie i wszechświecie, otwierając ją na swoje życie w komunii” ${ }^{33}$. Zobowiązanie ochrzczonego do naśladowania Chrystusa dotyka więc wszelkich relacji, jakie człowiek buduje idąc przez życie.

W tym sensie już św. Jan Paweł II mówił, że „naśladowanie Chrystusa jest pierwotnym i najgłębszym fundamentem chrześcijańskiej moralności”34. Chrześcijańska egzystencja ma charakter naśladowania, drogi, a co za tym idzie - kroczenia za Panem Jezusem upodabniając się przede wszystkim do Niego w miłości. Motywem podejmowanych przez chrześcijanina decyzji i działań ma być sam Bóg: kochać drugiego dla miłości Boga. Jest to typowo chrzcielny charakter życia moralnego osoby wierzącej, jako że strumień wody chrztu „włącza w dynamikę miłości Jezusa, źródło pewności dla naszej drogi życia" ${ }^{35}$.

${ }^{31}$ Por. LF, 41.

${ }^{32}$ Por. LF, 42.

33 Tamże.

${ }^{34}$ Jan Paweł II, Veritatis splendor, 19.

${ }^{35}$ LF, 42. 
Naturą miłości jest obdarowywanie: nie zamyka się ona w sobie, nie zamyka też osoby na drugą osobę. Jej wymiar relacyjny konstytuuje osobę w odniesieniu do drugiej osoby. Jeżeli życie Boga w Trójcy Przenajświętszej jest życiem miłości, to śmiało można stwierdzić, że odrodzenie, które dokonuje się przez chrzest, o czym mówi Franciszek, oznacza dla człowieka zaproszenie i zobowiązanie do uczestnictwa w życiu samego Boga: w miłości Boga i drugiego człowieka. Akceptacja siebie jako stworzenia uzdalnia do odkrycia sensu własnego istnienia. Przyjmując dar miłości człowiek staje się osobą budującą relację z Bogiem. Ta relacja kształtuje wszystkie inne, a więc stanowi fundament wolności i odpowiedzialności osoby $^{36}$. W miłości Chrystusa spotkała się miłość Boża z miłością ludzką, podobnie jak dar (będący jednocześnie zobowiązaniem) z najdoskonalszą odpowiedzią. Tak jak przez sakrament chrztu Bóg spotkał się z człowiekiem w Chrystusie, tak możliwe stało się dla człowieka żyjącego w komunii z Chrystusem przyjęcie daru miłości, jako wezwania do życia w dynamice miłości, do dawania świadectwa miłości.

Wiara, jako owoc chrztu, bez miłości byłaby tylko ideą, treścią czysto doktrynalną, możliwą do zdobycia $\mathrm{z}$ książki ${ }^{37}$. Wiara, rozumiana jako naśladowanie Chrystusa, potrzebuje miłości, by mogła się w pełni realizować. Daje siłę ochrzczonemu, by świadczyć poprzez uczynki o tej pewności, jaką jest miłość Boga dla jego życia. Bóg nie oczekuje od człowieka przyjęcia prawdy objawionej tylko sercem i umysłem, ale wyrażenia tego na zewnątrz, czyli przyznania się do Chrystusa ${ }^{38}$. Przykłady męczenników pokazują, jak owocne jest takie świadectwo w chwili próby oświeconej przez wiarę, gdy człowiek przekonuje się, że nie głosi samego siebie lecz Chrystusa (por 2 Kor 4,5) 39 . Męczeństwo jest najwyższym świadectwem prawdziwości życia w Chrystusie, owocnego życia łaską sakramentu chrztu świętego. Współdziałanie z łaską Bożą jest życiem ukierunkowanym na pełnię nowego życia w Chrystusie i potwierdzeniem prawdy o człowieku. Ochrzczony powinien więc przyjąć wobec Boga dziecięcą postawę zaufania $\mathrm{Mu}$, posłuszeństwa Jego woli, pokornego uznania niewystarczalności.

${ }^{36}$ Por. S. Bastianel, Storicità e assoluto in teologia morale, w: Morale e coscienza storica. In dialogo con Josef Fuchs, (Saggi, 26), red. S. Ferraro, Roma 1988, s. 87.

${ }^{37}$ Por. LF, 40.

${ }_{38}$ Por. J. Szymański, Zadania wierzących, s. 425.

39 Por. LF, 56. 
Przyjmując dar płynący z chrztu świętego ma podjąć zobowiązanie do naśladowania tej miłości, która obdarzyła go życiem.

Najpierw jest to powołanie do służby we wspólnocie Kościoła. Przynależąc do Chrystusa na mocy chrztu wierzący ma podjąć posługę wobec bliźniego. Wszystkie dzieła miłości i miłosierdzia nadają życiu sens, czynią je owocnym i odzwierciedlają chrzcielną tożsamość wierzącego. Wymiar wspólnotowy dodatkowo profiluje służbę miłości wzywając do dźwigania słabych, podnoszenia $\mathrm{z}$ upadku grzeszących dla dobra bliźniego (por. Rz 15,1-2). Podstawowym wezwaniem moralnym każdego ochrzczonego jest zatem postawa braterstwa i szukania jedności we wspólnocie wierzących ${ }^{40}$.

Chrzest niesie zatem także zobowiązanie do rozwijania życia cnotliwego. Wiara, nadzieja i miłość, jak również inne cnoty moralne mogą w człowieku rozwijać się i wzrastać. W ten sposób wierzący angażuje się w realizację powołania chrzcielnego. Prawdą jest, że u podnóża cnót leży łaska uświęcająca. Ona niesie z sobą dar miłości, który wzrasta wraz ze wzrostem stanu łaski uświęcającej w duszy. W tym mieści się znaczenie i rola Kościoła, który jest sakramentem spotkania Boga z człowiekiem. $\mathrm{Na}$ drodze sakramentalnej dokonuje się czerpanie ze źródeł łaski, wypływające ze spotkania z Chrystusem. Sakramenty ożywiają i powodują wzrost miłości w człowieku. Stąd też życie sakramentalne stoi w centrum rozwoju życia moralnego. W parze $\mathrm{z}$ sakramentami idą liturgia i modlitwa ${ }^{41}$.

Ostatecznym powołaniem wierzącego płynącym z sakramentu chrztu jest powołanie do świętości. Jest ona tym „zasadniczym ukierunkowaniem” i „pewnością dobrej przyszłości”, o których mówi Franciszek ${ }^{42}$. Chrzest otwiera w sposób zobowiązujący drogę prowadzącą do przeżywania pełni życia chrześcijańskiego, którą utożsamić należy ze świętością. Tą drogą jest właśnie naśladowanie Chrystusa, które wypełnia znamiona realizacji zobowiązań płynących $\mathrm{z}$ tego sakramentu. Chrzest czyni ludzi wybrańcami Bożymi powołanymi do świętości, których cechować powinny miłosierdzie, dobroć, pokora, cierpliwość, łagodność, zdolność do

${ }^{40}$ Por. J. Nagórny, Sakramenty w życiu moralnym chrześcijanina, Lublin 2011, s. 24 .

${ }^{41}$ Por. S. Olejnik, Teologia moralna fundamentalna, Włocławek 1998, s. 294-295.

${ }^{42}$ Por. LF, 43. 
przebaczania, zaangażowanie w służbę sprawiedliwości i na rzecz pokoju. W nim zakorzenione jest także wezwanie do ciągłego odradzania się chrześcijanin zostaje uświęcony przez Chrystusa, a jednocześnie powołany do współdziałania w dziele uświęcenia, a więc podjęcia odpowiedzialności za siebie i innych w duchu miłości ${ }^{43}$.

Podsumowując, papież Franciszek wyraźnie podkreśla, obok aspektu doktrynalnego, wymiar moralny sakramentu chrztu świętego. Nowość chrześcijańskiej egzystencji ma swoje źródło właśnie w nim. Otwiera projekt obejmujący całą rzeczywistość życia człowieka, co Franciszek stwierdza mówiąc, że jest to wejście na drogę przemiany całego życia ${ }^{44}$. W wodach chrztu umiera stary człowiek, a nowością staje się sam Chrystus, w którego ochrzczony się przyobleka. Odtąd życie prawdziwie wolne i w tej wolności odpowiedzialne może rozwijać się tylko w Chrystusie, do którego ochrzczony się upodobnił. Rozbudzenie nowego sakramentalnego sensu życia człowieka i egzystencji chrześcijańskiej nie może pozostać bez odpowiedzi. Konsekwencją jest życie moralne, którego bogactwo wyrazu tym bardziej potwierdza wielkość daru otrzymanego na chrzcie świętym.

Streszczenie. Chrzest święty - pierwszy z sakramentów, jaki człowiek przyjmuje w swoim życiu, stanowi fundament całej chrześcijańskiej egzystencji i wprowadza (wtajemnicza) w życie wiary. Pociąga za sobą zatem konsekwencje o charakterze moralnym, czyli wpływa i warunkuje osobowe życie chrześcijanina jako podmiotu wolnego, świadomego i odpowiedzialnego, który kieruje się w stronę dobra. Można więc mówić o moralnym wymiarze sakramentu chrztu świętego, na co wskazał papież Franciszek w swojej pierwszej encyklice Lumen fidei: „Człowiek otrzymuje w chrzcie naukę, którą ma wyznawać, oraz konkretną formę życia, która wymaga zaangażowania całej jego osoby i kieruje go w stronę dobra" (nr 41). Franciszek akcentuje, że chrzest święty jest sakramentem wiary. Poszukiwanie dobra jest kategorią moralną. Dotyczy osoby jako podmiotu wolnego, świadomego i odpowiedzialnego, która podejmując decyzje, dokonując wyboru Chrystusa, odpowiadając na dar nowego życia w Chrystusie, w wolności poszukując prawdy, kieruje się ku dobru. Przyjęcie chrztu ma wymiar fundamentalny dla chrześcijańskiej egzystencji, jest bowiem realizacją samej istoty bycia chrześcijaninem niesie z sobą odrodzenie, które otwiera drogę naśladowania Chrystusa.

Słowa kluczowe: chrzest; Lumen fidei; Franciszek.

${ }^{43}$ Por. S. Olejnik, Teologia moralna życia osobistego, dz. cyt., s. 33.

${ }^{44}$ Por. LF, 42. 
Abstract. Moral Dimension of the Sacrament of Baptism in the Light of Pope Francis Encyclical Lumen fidei. A baptism - the first of the sacrament that a person receives in a life, is the foundation of all Christian existence and introduce (initiate) into the life of faith. It implies the consequences of a moral character, that is, influences and conditions the personal life of the Christian as a free, conscious and responsible person who is moving towards the good. We can say about the moral dimension of the sacrament of baptism, as Pope Francis wrote in his first encyclical Lumen fidei: "In baptism we receive both a teaching to be professed and a specific way of life which demands the engagement of the whole person and sets us on the path to goodness" (n. 41). Francis states that holy baptism is the sacrament of faith. Searching for good is a moral category. It concerns a person as a free, conscious and responsible subject who, in making his choices, in choosing Christ, responding to the gift of a new life in Christ, in the freedom seeking the truth, is looking for the good. The baptism has a fundamental dimension for Christian existence because it is the realization of the very essence of being a Christian - it brings with it a rebirth which opens the way to imitate Christ.

Key words: Baptism; Lumen fidei; Francis.

\section{BIBLIOGRAFIA}

Hadalski J., Osobotwórczy charakter chrztu, Kraków 2006.

Kreeft P., Sakrament chrztu i bierzmowania, Warszawa 2011.

Misiurek J., Wiara i sakramenty w życiu duchowym, Częstochowa 2013.

Nagórny J., Sakramenty $w$ życiu moralnym chrześcijanina, Lublin 2011.

Olejnik S., Teologia moralna życia osobistego, Włocławek 1999.

Piegsa J., Człowiek - istota moralna. Religijne podstawy moralności. Wiara - nadzieja miłośc. Tom II, Opole 2002.

Przybyłowski J., Chrzest w praktyce duszpasterskiej, „Studia Włocławskie” 17(2015), s. 223-236.

Santantoni A., Iniziazione cristiana: concetto e realtà, w: Corso di morale. 5 - Liturgia. Etica della religiosità, red. T. Goffi, G. Piana, Brescia 1995, s. 123-160. 
